Gut, 1985, 26, 907-913

\title{
Influence of protein composition and hydrolysis method on intestinal absorption of protein in man
}

\author{
P P KEOHANE, G K GRIMBLE, BARBARA BROWN, R C SPILLER, \\ AND D B A SILK \\ From the Department of Gastroenterology and Nutrition, Central Middlesex Hospital, London
}

SUMMARY An intestinal perfusion technique has been used in normal human subjects to investigate the influence that starter protein composition and hydrolysis procedure have on absorption of amino acid residues from partial enzymic hydrolysates of whole protein. Five starter proteins were studied. Three (egg albumin, casein/soy/lactalbumin, and lactalbumin) were hydrolysed by papain, a second lactalbumin starter protein, and a meat/soy/lactalbumin blend were hydrolysed by a porcine pancreatic enzyme system. Irrespective of starter protein composition or hydrolysis method used, four amino acid residues (threonine, glutamic acid, phenylalanine, and histidine) were absorbed significantly faster from all hydrolysates compared with absorption from their equivalent free amino acid mixtures. In contrast, both starter protein composition and hydrolysis method influenced absorption characteristics of up to nine other amino acid residues.

The existence of a transport system capable of mediating the absorption of unhydrolysed di- and tripeptides from the human small intestine has now been established. ${ }^{1-4}$ Recently a number of studies have compared the absorption of amino acid residues during intestinal perfusion of either partial enzymic hydrolysates or whole protein (formulated to simulate the luminal products of dietary protein digestion) or of their equivalent free amino acid mixtures. ${ }^{5-7}$ The results suggested that significant quantities of dietary protein may be absorbed in the form of peptides rather than free amino acids, and one interesting feature of these data has been the variation in absorption characteristics exhibited by the different protein hydrolysates. ${ }^{7}$ This may have been because of the differing experimental conditions under which the various protein hydrolysates were studied. ${ }^{7}$

The aim of the present study was to investigate the possible factors which influence amino acid uptake from five partial enzymic hydrolysates of whole protein prepared using papain or pancreatic proteolytic enzyme systems. An in vivo steady state

Address for correspondence: Dr G K Grimble. Department of Gastroenterology and Nutrition. Central Middlesex Hospital. Acton Lane. London NW10 7NS

Received for publication 29 October 1984 perfusion technique has been used in normal human subjects, and throughout this study experimental conditions have been kept constant. During the course of the study, the opportunity was also taken to investigate what effects the different protein hydrolysates and their respective free amino acid mixtures exerted on water and electrolyte handling.

\section{Methods}

ENZYMIC HYDROLYSATES AND AMINO ACID MIXTURES

The partial enzymic hydrolysates were prepared using egg albumin, lactalbumin and blends of casein/soy/lactalbumin and meat/soy/lactalbumin as the starter proteins. They were hydrolysed in vitro under controlled conditions using enzyme systems based on the use of papain (lactalbumin I, egg albumin, casein/soy/lactalbumin blend) or a mixture of porcine pancreatic proteolytic enzymes (lactalbumin II, meat/soy/lactalbumin blend). The approximate size of the peptides in the final hydrolysates were estimated by gel filtration using Sephadex G10. Table 1 shows $85 \%$ of the amino acid content of the two lactalbumin, egg albumin casein/soy/ lactalbumin hydrolysates eluted in fractions corresponding to molecular weights of $<500$ daltons (free amino acids, di- to tetrapeptides) and $15 \%$ in 
Table 1 Starter proteins, hydrolysis methods and estimates of molecular weight profile of the resultant partial enzymic hydrolysates

\begin{tabular}{|c|c|c|c|c|}
\hline \multirow[b]{2}{*}{ Starter proteins } & \multirow[b]{2}{*}{ Enzyme system } & \multicolumn{3}{|c|}{$\begin{array}{l}\text { Elution profiles during Sephadex G10 chromatography } \\
\text { Amino acid nitrogen }(\%)\end{array}$} \\
\hline & & $M W<500$ & $M W 500-2000$ & $M W>2000$ \\
\hline Egg albumin & Papain & $85-90$ & 15 & None \\
\hline Lactalbumin I & Papain & $85-90$ & 15 & None \\
\hline Lactalbumin II & Pancreatic proteases & $85-90$ & 15 & None \\
\hline Meat/soy/lactalbumin & Pancreatic proteases & $35-40$ & $15-20$ & $35-40$ \\
\hline
\end{tabular}

fractions corresponding to molecular weights of higher peptides. The meat/soy/lactalbumin hydrolysate differed from the other four preparations in that $35-40 \%$ of the amino acid nitrogen eluted in fractions corresponding to molecular weights $<500$ daltons, $15-20 \%$ in fractions $500-200$ daltons, and $35-40 \%$ in fractions $>2000$ daltons.

The amino acid composition of the five hydrolysates was determined by ion exchange chromatography after complete acid hydrolysis, ${ }^{89}$ as described in the methods section and is shown in Table 2.

Equivalent free amino acid mixtures simulating the pattern and molar concentration of the partial enzymic hydrolysate of whole protein (Table 2) were prepared using crystalline L-amino acid isomers (Sigma Chemical Co, Poole, Dorset).

\section{PERFUSION TECHNIQUE AND EXPERIMENTAL} DESIGN

Nineteen normal volunteers, aged 20-27 years, were intubated with a double lumen perfusion tube, incorporating a proximal occlusive balloon. ${ }^{10}$ The study was approved by the Ethical Committee of the Central Middlesex Hospital, and informed consent was obtained from all volunteers. The tube was allowed to pass until the infusion orifice was positioned at the duodenojejunal junction, the position being checked radiologically to confirm that the $25 \mathrm{~cm}$ perfusion segment was correctly positioned in the proximal jejunum.

Test solutions were perfused at $20 \mathrm{ml} / \mathrm{min}$. To ensure adequate washout the isolated segment was perfused with normal saline for 30 minutes and under these conditions we were unable to detect amino acids in the saline aspirate. Thereafter the segment was perfused in random order with the test solutions and after a 30 minute equilibration period, three 10 minute samples were collected from the distal collection orifice by simple syphonage into a vessel at $4^{\circ} \mathrm{C} .{ }^{12} 13$ Immediately after collection samples were divided into two aliquots, one of which was stored at $-20^{\circ} \mathrm{C}$ until analysis of PEG and

Table 2 Amino acid composition of the protein hydrolysate solutions ( $\mu$ molll). Values are mean $\pm S E$

\begin{tabular}{|c|c|c|c|c|c|}
\hline Amino acid & $\begin{array}{l}\text { Lactalbumin I } \\
\text { (papain) }\end{array}$ & $\begin{array}{l}\text { Lactalbumin II } \\
\text { (pancreatic) }\end{array}$ & $\begin{array}{l}\text { Casein/soy/ } \\
\text { lactalbumin } \\
\text { (papain) }\end{array}$ & $\begin{array}{l}\text { Egg albumin } \\
\text { (papain) }\end{array}$ & $\begin{array}{l}\text { Meat/soy/ } \\
\text { lactalbumin } \\
\text { (pancreatic) }\end{array}$ \\
\hline Aspartic acid + asparagine & $9 \cdot 5 \pm 0 \cdot 4$ & $7 \cdot 1 \pm 0 \cdot 5$ & $8 \cdot 0 \pm 0 \cdot 4$ & $9 \cdot 5 \pm 0 \cdot 5$ & $8 \cdot 5 \pm 0 \cdot 8$ \\
\hline Threonine & $5 \cdot 8 \pm 0 \cdot 4$ & $5 \cdot 5 \pm 0 \cdot 5$ & $7 \cdot 8 \pm 0 \cdot 5$ & $5 \cdot 1 \pm 0 \cdot 4$ & $4 \cdot 5 \pm 0 \cdot 5$ \\
\hline Serine & $8 \cdot 2 \pm 0 \cdot 3$ & $8 \cdot 0 \pm 0 \cdot 5$ & $9 \cdot 2 \pm 0 \cdot 4$ & $9 \cdot 0 \pm 0 \cdot 3$ & $6 \cdot 5 \pm 0 \cdot 3$ \\
\hline Glutamine + glutamic acid & $16 \cdot 8 \pm 1 \cdot 9$ & $17 \cdot 2 \pm 2 \cdot 3$ & $16 \cdot 2 \pm 2 \cdot 1$ & $11 \cdot 6 \pm 1 \cdot 7$ & $13 \cdot 9 \pm 1.8$ \\
\hline Alanine & $9 \cdot 0 \pm 0 \cdot 4$ & $6 \cdot 8 \pm 0 \cdot 3$ & $8 \cdot 9 \pm 0 \cdot 3$ & $9 \cdot 5 \pm 0 \cdot 3$ & $8 \cdot 2 \pm 0 \cdot 4$ \\
\hline Valine & $6 \cdot 6 \pm 0 \cdot 2$ & $7 \cdot 2 \pm 0.4$ & $7 \cdot 4 \pm 0 \cdot 3$ & $6 \cdot 0 \pm 0 \cdot 2$ & $6 \cdot 3 \pm 0 \cdot 3$ \\
\hline Cystine & $0 \cdot 8 \pm 0 \cdot 2$ & - & $0 \cdot 9 \pm 0 \cdot 2$ & $1 \cdot 1 \pm 0 \cdot 3$ & $0 \cdot 3 \pm 0 \cdot 1$ \\
\hline Methionine & $1 \cdot 5 \pm 0 \cdot 2$ & $2 \cdot 0 \pm 0 \cdot 1$ & $1 \cdot 5 \pm 0 \cdot 2$ & $3 \cdot 9 \pm 0 \cdot 3$ & $1 \cdot 8 \pm 0 \cdot 1$ \\
\hline Isoleucine & $4 \cdot 7 \pm 0 \cdot 2$ & $5 \cdot 0 \pm 0 \cdot 2$ & $4 \cdot 2 \pm 0 \cdot 3$ & $5 \cdot 6 \pm 0 \cdot 2$ & $4 \cdot 7 \pm 0 \cdot 2$ \\
\hline Leucine & $11 \cdot 4 \pm 0.9$ & $9 \cdot 4 \pm 0.8$ & $10 \cdot 4 \pm 0 \cdot 9$ & $8 \cdot 9 \pm 0.7$ & $4 \cdot 7 \pm 0 \cdot 3$ \\
\hline Tyrosine & $2 \cdot 1 \pm 0 \cdot 3$ & $1 \cdot 9 \pm 0 \cdot 2$ & $2 \cdot 5 \pm 0 \cdot 1$ & $3 \cdot 2 \pm 0 \cdot 2$ & $2 \cdot 7 \pm 0 \cdot 2$ \\
\hline Phenylalanine & $2 \cdot 3 \pm 0 \cdot 2$ & $2 \cdot 5 \pm 0 \cdot 2$ & $2.9 \pm 0.3$ & $4 \cdot 7 \pm 0 \cdot 2$ & $3 \cdot 7 \pm 0 \cdot 3$ \\
\hline Lysine & $4 \cdot 3 \pm 0 \cdot 3$ & $10 \cdot 2 \pm 0 \cdot 4$ & $3 \cdot 5 \pm 0 \cdot 2$ & $2 \cdot 2 \pm 0 \cdot 2$ & $2 \cdot 8 \pm 0 \cdot 2$ \\
\hline Arginine & $1 \cdot 8 \pm 0 \cdot 2$ & $1 \cdot 7 \pm 0 \cdot 2$ & $2 \cdot 7 \pm 0 \cdot 2$ & $3 \cdot 6 \pm 0 \cdot 3$ & $3 \cdot 9 \pm 0.3$ \\
\hline Proline & $10 \cdot 4 \pm 0.4$ & $11 \cdot 7 \pm 0 \cdot 7$ & $3 \cdot 7 \pm 0 \cdot 2$ & $3 \cdot 7 \pm 0 \cdot 2$ & $9 \cdot 5 \pm 0.7$ \\
\hline
\end{tabular}


electrolyte content, and the other was treated with sulphosalicyclic acid to inhibit luminal peptidase activity, centrifuged and the supernatant used for amino acid analysis. ${ }^{12} 13$

The experiment design compared the extent of absorption of amino acid residues from the partial enzymic hydrolysates of whole protein and their respective free amino acid mixtures. ${ }^{7}$ In 16 subjects the small intestine was perfused with two pairs of solutions in random order, comprising one of the protein hydrolysates and its equivalent free amino acid solution and in three subjects only one pair of solutions was perfused to complete the study. Thus in effect, for each hydrolysate the following number (n) of perfusions were performed: casein/soy/lactalbumin (6), lactalbumin I (5), lactalbumin II (6), meat/soy/lactalbumin (6), egg albumin (7).

All test solutions contained $100 \mathrm{mmol} \propto$ amino acid nitrogen/litre and, by the addition of sodium chloride $(120 \mathrm{mmol} / \mathrm{l}$ to the protein hydrolysates; $105 \mathrm{mmol} / \mathrm{l}$ to free amino acid solutions) were rendered isotonic to plasma $(285-295 \mathrm{mOsm} / \mathrm{kg})$. The test solutions also contained ${ }^{14} \mathrm{C}$ polyethylene glycol (Amersham International, Bucks) at a concentration of $1 \mu \mathrm{Ci} / 1$ and $5 \mathrm{~g} / \mathrm{l} \mathrm{PEG},{ }^{11}$ and the $\mathrm{pH}$ of all solutions was adjusted to $7 \cdot 0$ before perfusion, using $0 \cdot 1 \mathrm{M}$ sodium hydroxide. All solutions were perfused at $20 \mathrm{ml} / \mathrm{min}$.

\section{ANALYTICAL TECHNIQUE}

Aliquots of the perfusion solutions and their respective intestinal aspirates were hydrolysed under nitrogen at $110^{\circ} \mathrm{C}$ for 18 hours with $6 \mathrm{~N}$ hydrochloric acid with norleucine added as an internal standard. The amino acid content of the hydrolysed samples was estimated by ion exchange chromatography using a Locarte Automatic Loading Amino Acid Analyser (Locarte Co, London). The PEG content of the test solutions and intestinal aspirates were measured by scintillation counting (Packard Tricarb Liquid Scintillation Counter) and the sodium content by flame photometry (EEL Ltd, Essex, UK). Rates of sodium, water and amino acid absorption were calculated using previously described formulae. ${ }^{14-16}$ Luminal disappearance of individual amino acid residues (absorption) is expressed as percentage of infused load. Significance of difference between mean values was assessed by the Student's paired $t$ test.

\section{Results}

\section{AMINO ACID ABSORPTION}

There was considerable variation in the extent of absorption of individual amino acid residues from the free amino acid solutions, but phenylalanine, threonine, glutamic acid and histidine were poorly absorbed from all solutions (Table 3 ). These marked differences in absorption of amino acid residues from the respective partial enzymic hydrolysates of whole protein were not observed (Table 3) as, in general, residues that were poorly absorbed from free amino acid solutions were absorbed to a greater extent from the protein hydrolysates. Thus threonine, glutamic acid, phenylalanine and histidine were absorbed significantly faster from all protein hydrolysate solutions than from equivalent free amino acid mixtures ( $<<0.05$ or less).

\section{INFLUENCE OF STARTER PROTEIN COMPOSITION (Table 3)}

There were considerable differences in absorption of amino acid residues from the three papain hydrolysates. Thus only four residues (thre, glu, phe, his) were absorbed faster from the egg albumin hydrolysate than from the equivalent free amino acid mixtures, but seven residues (thr, glu, phe, his, asp, gly, ala) were absorbed faster from the lactalbumin hydrolysate and 13 (thr, glu, phe, his, arg, tyr, leu, ser, gly, ala, val, lys, asp) from the casein/soy/ lactalbumin blend when compared with equivalent free amino acid mixtures.

INFLUENCE OF HYDROLYSIS PROCEDURE (Table 3 ) Seven amino acid residues (asp, glu, phe, his, thr, gly, ala) were absorbed faster from the papain hydrolysate of lactalbumin compared with its equivalent free amino acid mixture, while nine residues (asp, glu, phe, his, thr, arg, tyr, leu, ser) were absorbed faster from the pancreatic hydrolysate of lactalbumin compared with its equivalent free amino acid mixture.

The second pancreatic hydrolysate, the meat/soy/ lactalbumin blend, differed from the four others in that it contained a greater proportion of higher molecular weight peptides $(20 \% 500-2000 ; 40 \%$ $<2000$, Table 1). Nevertheless seven amino acid residues (thr, glu, phe, his, asp, tyr, val) were absorbed faster from this hydrolysate than from its equivalent free amino acid mixture.

SODIUM AND WATER HANDLING (Table 4)

All five protein hydrolysates and their equivalent free amino acid mixtures stimulated net jejunal sodium and water absorption. There was no significant differences between the effects of the different protein hydrolysates on sodium and water handling, nor between the effects of the different free amino acid mixtures. Finally, each pair of protein hydrolysates and equivalent free amino acid mixtures stimulated sodium and water absorption to a similar degree. 
Table 4 Sodium and water absorption during jejunal perfusion of protein hydrolysates and their equivalent free amino acid mixtures (mean $\pm S E$ )

\begin{tabular}{|c|c|c|c|}
\hline Perfusion solution & $N^{*}$ & $\begin{array}{l}\mathrm{Na}^{+} \text {absorption } \\
(\mathrm{mm} / \mathrm{h} / 25 \mathrm{~cm})\end{array}$ & $\begin{array}{l}\mathrm{H}_{2} \mathrm{O} \text { absorption } \\
(\mathrm{ml} / \mathrm{h} / 25 \mathrm{~cm})\end{array}$ \\
\hline $\begin{array}{l}\text { Lactalbumin I } \\
\quad \text { (porcine pancreatic) }\end{array}$ & 5 & $22 \pm 5$ & $116 \pm 32$ \\
\hline AA mixture & & $10 \pm 4$ & $163 \pm 9$ \\
\hline Lactalbumin II (papain) & 6 & $14 \pm 6$ & $112 \pm 42$ \\
\hline AA mixture & & $10 \pm 2$ & $125 \pm 52$ \\
\hline $\begin{array}{l}\text { Casein/soy/lactalbumin } \\
\text { (papain) }\end{array}$ & 6 & $8 \pm 4$ & $116 \pm 26$ \\
\hline AA mixture & & $10 \pm 3$ & $163 \pm 9$ \\
\hline Egg albumin (papain) & 7 & $19 \pm 6$ & $135 \pm 41$ \\
\hline AA mixture & & $17 \pm 4$ & $173 \pm 36$ \\
\hline $\begin{array}{l}\text { Meat/soy/lactalbumin } \\
\text { (porcine pancreatic) }\end{array}$ & 6 & $17 \pm 4$ & $107 \pm 27$ \\
\hline AA mixture & & $10 \pm 2$ & $147 \pm 27$ \\
\hline
\end{tabular}

Each pair of solutions, comprising a protein hydrolysate and its equivalent free amino acid mixture was perfused in the number of subjects indicated.

\section{Discussion}

These results show that irrespective of differences in starter protein composition and hydrolysis method used, four amino acid residues (thr, glu, phe, his), comprising approximately $28 \%(26-29 \%)$ of total amino acid composition of the starter proteins, were absorbed significantly faster from all five partial enzymic hydrolysates than from their equivalent free amino acid mixtures. These four amino acid residues are included in a group of amino acids poorly absorbed from all the free amino acid solutions, as Table 3 shows, and this suggests that they have a low affinity for their respective group specific amino acid transport system. The wide variation in uptake of amino acids from equimolar ${ }^{7}$ as well as heterogeneous amino acid mixtures $^{2} 41718$ has been shown before, and can be ascribed not only to the differing affinities of individual amino acids for the group specific amino acid transport systems but also to the effects of competitive inhibition by other amino acids with a higher affinity for shared transport systems.

The kinetic advantage conferred by all hydrolysates on uptake of thr, glu, phe and his is likely to occur because absorption of these amino acid residues is mediated by peptide rather than free amino acid systems. This, in turn, suggests either that high proportions of thr, glu, phe and his liberated from the different proteins during hydrolysis are present as di- or tripeptides, or that under the present experimental conditions such marked differences exist between the rates of peptide bound and free amino acid transport of these residues that differences in extent of absorption from the hydrolysates and free amino acid mixtures become evident, even if relatively small proportions of these amino acid residues contained in the hydrolysate are present in the peptide bound form. Whatever the explanation, it is clear that, under the present experimental condition, neither the composition of starter protein nor hydrolysis procedure has a pronounced effect on intestinal uptake of these four amino acid residues from partial enzymic hydrolysates of whole protein.

Considerable variation occurred in other absorption characteristics of the five hydrolysates. Thus, a total of 13 amino acid residues were absorbed faster from the casein/soy/lactalbumin hydrolysate as compared with its equivalent free amino acid mixture, where as asp, glu, phe and his were the only four residues absorbed faster from the egg albumin hydrolysate. Different combinations of seven to nine residues were absorbed faster from the three other hydrolysates.

Previous perfusion studies have also shown variation in absorption characteristics between partial enzymic hydrolysates of whole protein and their equivalent free amino acid mixtures, ${ }^{2351920}$ but as these studies were carried out using differing experimental conditions, ${ }^{7}$ direct comparison of the various data is difficult. In the present study, however, identical experimental conditions were used for all five experiments, so differences observed can be ascribed either to starter protein source or hydrolysis method used. To compare the influence of hydrolysis procedures on intestinal handling, two lactalbumin preparations of similar amino acid composition (Table 2) were hydrolysed by either papain or pancreatic based enzyme systems producing two different protein hydrolysates, although of similar peptide molecular weight distribution (Table 1).

The resultant hydrolysates differed in both the total number and composition of amino acid residues absorbed faster from the hydrolysates compared with their equivalent free amino acid mixtures. The peptide molecular weight distribution of the two hydrolysates was similar (Table 1), but the papain and pancreatic based enzyme systems are likely to have produced qualitative changes in amino acid composition of the two peptide fractions, so influencing net absorption of different amino acid residues from each hydrolysate.

Differences in absorption characteristics were also seen when three different starter protein mixtures were hydrolysed by the same papain method (Table 3 ). Again the molecular weights of the peptide fractions were similar (Table 1), suggesting that 
qualitative changes in peptide composition produced by the use of different starter proteins will influence absorption characteristics of individual amino acids contained in the resultant hydrolysate.

The four hydrolysates discussed above contained peptide fractions of similar molecular weight distribution, and comprised almost entirely di- and tripeptides. The meat/soy/lactalbumin hydrolysate differed markedly because it contained a relatively greater proportion of high molecular weight peptides (15-20\% 500-2000; 40\% >2000). Despite this, the hydrolysate still conferred a kinetic advantage to absorption of seven amino acid residues. Although previous studies indicate that di- and tripeptides are absorbed intact by the human small intestine, ${ }^{1-4}$ evidence suggests that brush border peptide hydrolases play a pivotal role in the assimilation of higher peptides. ${ }^{21-24}$

Kim and Brophy ${ }^{24-26}$ have shown that mammalian intestine contains brush border protein hydrolases capable of hydrolysing peptides of chain length up to six amino acid residues. One interpretation of the results obtained with the meat/soy/lactalbumin hydrolysate (containing a preponderance of the high molecular weight peptide fraction) is, therefore, that brush border hydrolysis of the high molecular weight peptide fraction is not rate limiting with respect to transport of its constituent amino acid residues. Further studies with more purified peptide fractions of different molecular weight range are needed before this suggestion can be confirmed.

Although water secretion has been previously reported with a fish protein hydrolysate, ${ }^{7}$ all the protein hydrolysates and their respective free amino acids used in the present study had a stimulatory effect on water and electrolyte transport.

While the present results do suggest that the nature of the starter protein and type of hydrolysis procedure both exert some influence of the absorptive characteristics of the partial enzymic hydrolysates of the whole protein, care should be taken not to extrapolate any of these experimental findings to the formulation of the peptide components of enteral diets. This is because in the present experiment amino acid residues were delivered to the small intestine at a load of $1200 \mu \mathrm{mol} / \mathrm{min}$, whereas during enteral nutrition where diets are administered by continuous 24 hour infusion, the load administered is in the range of $400-800 \mu \mathrm{mol} / \mathrm{min}$. The human perfusion studies recently reported by Hegarty ${ }^{27}$ and colleagues indicate that differences between amino acid residue uptake from protein hydrolysates and equivalent free amino acid mixtures are dependent upon load administered. Thus it does not necessarily follow that the protein hydrolysate found to confer the greatest kinetic advantage on amino acid residue uptake in the present study is the one that will do so when used clinically.

We are grateful to the Medical Research Council for financial support.

\section{References}

1 Matthews DM. Protein absorption. J Clin Pathol 1971; 5: suppl 24: $29-40$.

2 Matthews DM. Intestinal absorption of peptides. Physiol Rev 1975; 55: 537-608.

3 Matthews DM, Adibi SA. Peptide absorption. Gastroenterology 1976; 71: 151-61.

4 Silk DBA, Dawson AM. Intestinal absorption of carbohydrate and protein in man. In: Crane RK, ed. International Review of Physiology. Gastrointestinal Physiology III. Baltimore: University Park Press, 1979: 151-204.

5 Silk DBA, Marrs TL, Addison JM, Burston D, Clark ML, Matthews DM. Absorption of amino acids from an amino acid mixture simulating casein and a tryptic hydrolysate of casein in man. Clin Sci Mol Med 1973; 45: 715-9.

6 Silk DBA, Clark ML, Marrs TL et al. Jejunal absorption of an amino acid mixture simulating casein and an enzymic hydrolysate of casein prepared for oral administration to normal adults. Br $J$ Nutr 1975; 33: 95-100.

7 Silk DBA, Fairclough PD, Clark ML et al. Uses of a peptide rather than free amino acid nitrogen source in chemically defined 'elemental' diets. J Parent Ent Nutr 1980; 4: 6: 548-53.

8 Woodham AA. A survey of user experience with automated amino acid analysers. Proc Nutr Soc 1974; 33: 95A.

9 Rees MW. The estimation of threonine and serine in proteins. Biochem J 1946; 40: 632-40.

10 Sladen GE, Dawson AM. Further studies on the perfusion method for measuring intestinal absorption in man: the effects of a proximal occlusive balloon and a mixing segment. Gut 1970; 11: 947-54.

11 Wingate DL, Sandberg RJ, Phillips SF. A comparison of stable and ${ }^{14} \mathrm{C}$ labelled polyethylene glycol as volume indicators in the human jejunum. Gut 1972; 13: 812-4.

12 Silk DBA, Nicholson JA, Kim YS. Hydrolysis of peptides within lumen of small intestine. Am J Physiol 1976; 231: 1322-9.

13 Silk DBA, Chung KL, Berger K et al. Comparison of oral feeding of peptide and amino acid meals to normal human subjects. Gut 1979; 20: 291-9.

14 Adibi SA. Intestinal transport of dipeptides in man: importance of hydrolysis and intact absorption. J Clin Invest 1971; 50: 2266-75.

15 Silk DBA, Perrett D, Clark ML. Intestinal transport of two dipeptides containing the same two neutral amino acids in man. Clin Sci Mol Med 1973; 45: 291-9.

16 Sladen GE, Dawson AM. Inter-relationships between 
the absorption of glucose, sodium and water by the normal human jejunum. Clin Sci Mol Med 1969; 36: 119-32.

17 Adibi SA. Influence of molecular structure of neutral amino acids on their absorption kinetics in the jejunum and ileum of human intestine in vivo. Gastroenterology 1969; 56: 903-13.

18 Adibi SA, Gray SJ. Intestinal absorption of essential amino acids in man. Gastroenterology 1967; 52: 837-45.

19 Silk DBA. Peptide absorption in man. Gut 1974; 15: 494-501.

20 Adibi SA. Intestinal phase of protein assimilation in man. Am J Clin Nutr 1976; 29: 205-13.

21 Adibi SA, Morse EL. The number of glycine residues which limit intact absorption of glycine oligopeptides in human jejunum. J Clin Invest 1979; 60: 1008-16.

22 Kania RK, Santiago NA, Gray GM. Intestinal surface amino-oligopeptidases. II. Substrate kinetics and topography of the active site. J Biol Chem 1977; 252: 4929-34.

23 Silk DBA. Peptide transport. Clin Sci 1981; 60: 607-13.

$24 \mathrm{Kim}$ YS, Kim YW, Sleisenger MH. Studies on the properties of peptide hydrolyases in the brush border and soluble fractions of the small intestinal mucosa of rat and man. Biochem Biophys Acta 1974; 370: 283-96.

25 Kim YS, Brophy EJ, Nicholson JA. Rat intestinal brush border membrane peptidases. J Biol Chem 1976; 251: 3206-12.

26 Kim YS, Brophy EJ. Effect of amino acids on purified rat intestinal brush border membrane aminooligopeptidase. Gastroenterology 1979; 76: 82-7.

27 Hegarty JE, Moriarty HJ, Fairclough PD, Clark ML. Effect of concentration on amino acid absorption from a protein hydrolysate and an equivalent amino acid mixture. [Abstract] Gut 1981; 5: A430. 